\title{
Post treatment of Water for Human Consumption for Removal of Toxic Compounds - Mini Review
}

\author{
Tonhato $\mathrm{A}^{1 *}$ and Marteli AT ${ }^{2}$ \\ ${ }^{1}$ Chemical Engineering Department, State University of West of Paraná (UNIOESTE), \\ Brazil \\ ${ }^{2}$ Biochemical Pharmaceutics and medical student at UNIOESTE, Brazil
}

Mini Review

Volume 4 Issue 2

Received Date: April 18, 2019

Published Date: May 03, 2019

DOI: $10.23880 /$ act-16000156

*Corresponding author: Alcides Tonhato, Chemical Engineering Department, State

University of West of Paraná (UNIOESTE)-Unioeste, Rua da Faculdade, 645, Toledo-PR, 85903000, Brazil, Tel: +55-4533797036; Email: alcidestonhato@hotmail.com

\section{Abstract}

The treatment of water for human consumption uses chemical /physical/biological processes to guarantee the potability and to avoid contaminations due to toxic compounds. The treatment of drinking water employs the following principal processes: 1) coagulation/flocculation/ sedimentation for removal of suspended particles, generally using aluminum sulfate flocculant due to the low cost and wide application range, however in high concentrations it is toxic for humans, after; 2) rapid filtration is performed to remove the remaining suspended particles via mechanical action, and activated carbon is also used to remove chemical compounds via adsorption, however, it is possible that particles and chemical compounds are not retained; 3 ) as last step the adjustment of $\mathrm{pH}$, the addition of chlorine and fluorine, but, the reaction of chlorine with the residual carbon can generate trihalomethanes, which is also toxic to humans. In view of this scenario, this mini article aims to present in a resumid way: a) the possible toxic substances present in water for human consumption and b) an efficient method for post-treatment water in your home.

\section{Introduction}

\section{The Possible Toxic Substances Present in Water for Human Consumption}

Among the chemicals that can be used as coagulants in the water treatment, the principal are: aluminum sulfate, ferric chloride, sulfates ferrous chloride, ferric sulfate, aluminum hydroxychloride, aluminum polychloride (PAC), among others [1]. Aluminum sulphate is widely used, however in high concentrations it is toxic and can cause some diseases like dementia, damage to the system central nervous, memory loss, deafness, strong tremors, muscle aches, cramps, weakness or inappetence. It has been suggested that aluminum may be related to
Alzheimer's disease, although this hypothesis has not conclusive evidence [2,3]. Problems associated with the use of inorganic coagulants based on iron and aluminum salts, motivated the interest of investigators to seek alternatives to the use of these coagulants. Another factor that can cause toxicity to water is persistent organic pollutants (POP's). According to Jones and Voogt, POPs are defined in the following terms: POPs are typically 'water-hating' and 'fat-loving' chemicals, i.e. hydrophobic and lipophilic [4]. In aquatic systems and soils they partition strongly to solids, notably organic matter, avoiding the aqueous phase. They also partition into lipids in organisms rather than entering the aqueous milieu of cells and become stored in fatty tissue. This 
confers persistence on the chemical in biota since metabolism is slow and POPs may therefore accumulate in foodchains [4].

There are 12 substances or substance groups prioritized for global action in the recently signed Stockholm Convention on Persistent Organic Pollutants, including dieldrin, aldrin, endrin, chlordane, heptachlor, DDT, toxaphene, mirex, two kinds of industrial chemicals [polychlorinated biphenyls (PCBs) and hexachlorobenzene (HCB)], and two kinds of byproducts (polychlorinated dibenzofurans and polychlorinated dibenzo-p-dioxins). Much attention is given to POP contamination problems, highlighting, reproductive, developmental, behavioral, neurological, endocrine, and immune adverse health effects on people have been linked to POPs [5].

Pamplona-Silva, et al. in his article entitled "Estrogenic Compounds: Chemical Characteristics, Detection Methods, Biological and Environmental Effects" explains variety of chemical compounds found in the environment may lead to many detrimental disorders in organisms, due to the possibility of the interaction of these compounds with cellular components [6]. Some of them can also induce hormonal responses, similar to those produced naturally by organisms.

Some cyanobacteria, such as dinoflagellates, can proliferate in water releasing toxins into the water, leading to intoxication in humans, even in the absence of the microorganism. The inorganic contaminant of greatest concern in groundwater is the nitrate ion, $\mathrm{NO}_{3}{ }^{-}$, which normally occurs in aquifers in rural and suburban areas.
Nitrate in groundwater originates mainly from four sources: fertilizer application with nitrogen, as well as inorganic and animal manure, in plantations; soil cultivation; sewage deposited in septic systems and atmospheric deposition. Excess nitrate ion in drinking water is worrisome because it causes blue-baby syndrome in newborns (methemoglobinemia); and in adults, according to surveys, may be responsible for causing stomach cancer, and increasing the likelihood of breast cancer in women [7].

Disinfection is the last step in the water treatment processes for the protection of public health. Trihalomethanes (THMs) are common contaminants of chlorinated drinking water. The presence of THMs in chlorinated drinking water can pose a severe health threat due to its potential carcinogenicity. Epidemiological studies have been conducted to investigate the correlations between chlorination byproducts and several diseases. Been reported that the trihalomethanes in drinking water will increase the cancer risks of bladder and cause reproductive defects (Gen-Shuh Wang, et al. [8]. In view of this scenario it is proposed an efficient method for post-treatment water in your home, for the removal of toxic substances $[9,10]$.

\section{Method for Post-Treatment Water in your Home}

In Brazil, so-called clay filters or water filters (ceramic containers equipped with slow filters) have gained consumer acceptance and have become the domestic filtering equipment most used by the population. As can be seen from Figure 1.

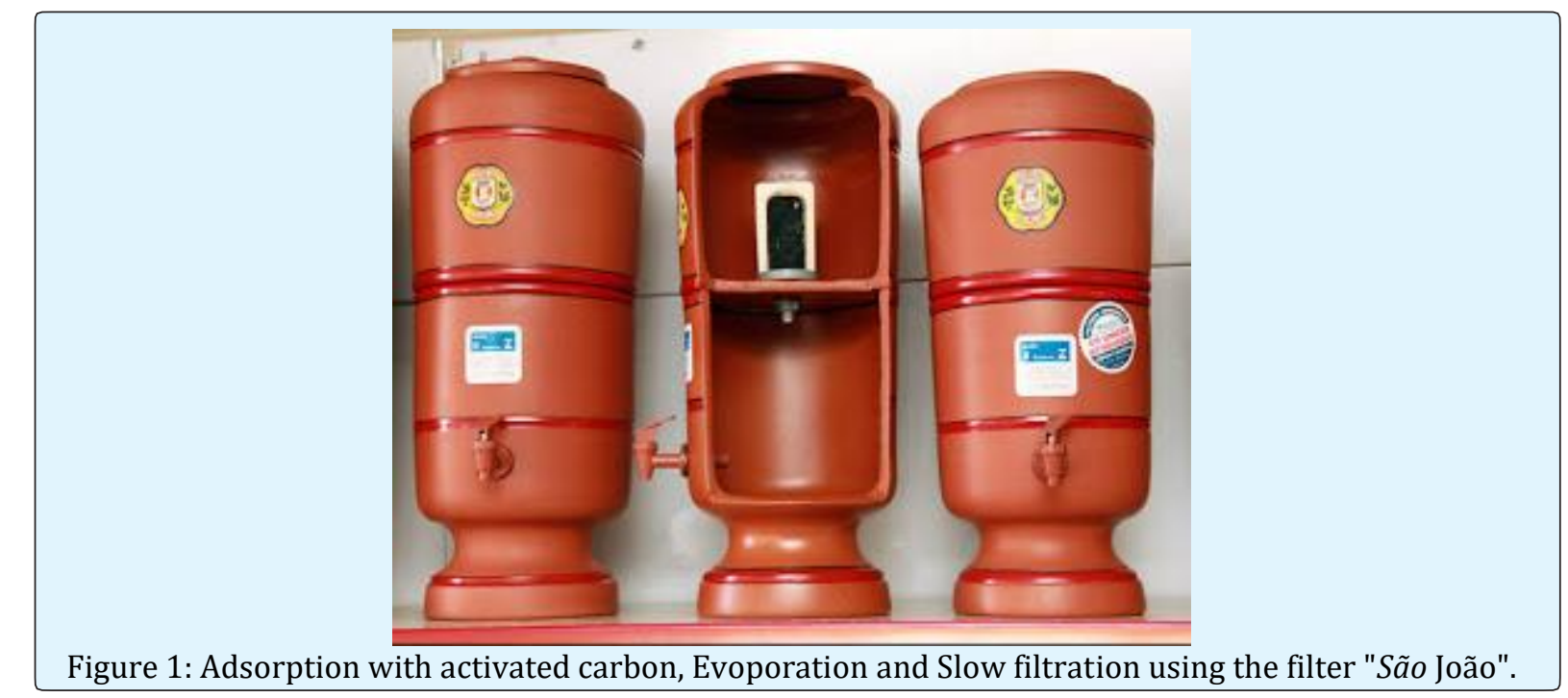

Tonhato A and Marteli AT. Post treatment of Water for Human Consumption for Removal of Toxic Compounds - Mini Review. Adv Clin Toxicol 2019, 4(2):

Copyright(C) Tonhato A and Marteli AT. 000156 


\section{Advances in Clinical Toxicology}

The operating principle is slow filtration using gravity. Water passes through the filter, providing mechanical retention of particulates as well as adsorbing chemical compounds such as POPs and chlorine. Slow filtration has been outstanding in relation to rapid filtration due to high efficiency in the separation of toxic compounds. Figure 2 shows the operating mechanism.

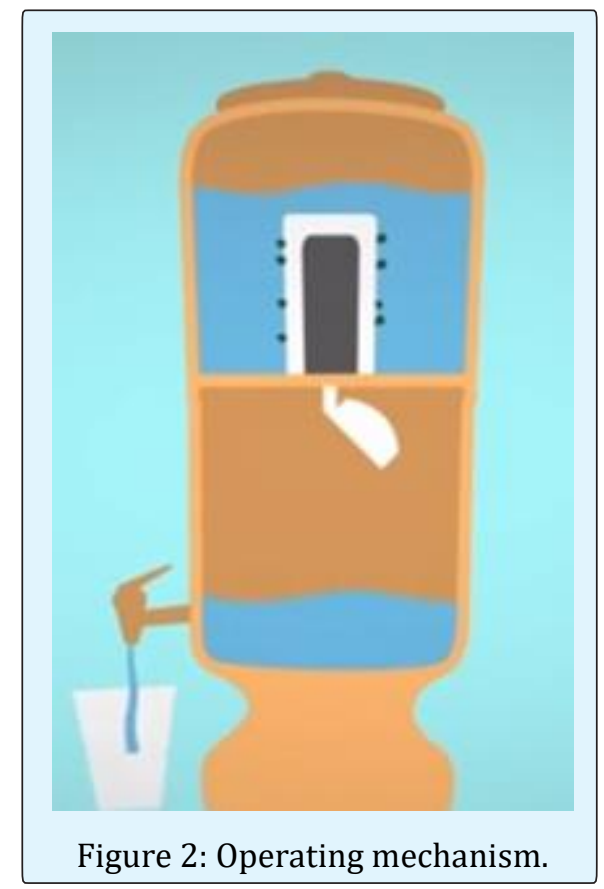

\section{Conclusion}

It has been found that it is possible to find toxic compounds in drinking water; however, there are tools and methods to enhance the post treatment in order to improve water conditions for human consumption. This precaution with the quality of drinking water is part of the primary prevention of conditions associated with the intake of improper water. As cited in this paper, damage to the central nervous system and dementia can be caused by excess of some chemical compounds used in treatment. With the aging population and the epidemiological transition that the world is currently experiencing, this factor assumes relevant importance and it has an important social and economic repercussions that can have an impact on public health in general.

\section{References}

1. Vaz LGL (2009) Performance do processo de coagulação/floculação no tratamento do efluente líquido gerado na galvanoplastia. Dissertação de mestrado em Engenharia Química UNIOESTE, pp: 100.

2. Tonhato A, Morejon CFM, Hasan SDM (2019) Study of the operation of a continuous modular bioreactor used for treatment of wastewater from a recycling industry of by-products from slaughterhouses. Water, Air, \& Soil Pollution 230: 82.

3. Cleto, CITP (2008) 0 alumínio na água de consumo humano. Dissertação de mestrado apresentada à Universidade da Beira Interior, Covilhã 2008.

4. Jones KC, de Voogt P (1999) Persistent organic pollutants (POPs): state of the science. Environmental Pollution 100(1-3): 209-221.

5. Wang Tieyu, Lu Yonglong, Zhang Hong, Shi Yajuan (2005). Contamination of persistent organic pollutants (POPs) and relevant management in China. Environ Int 31(6): 813-821.

6. Pamplona-Silva MT, Mazzeo DEC, Bianchi J, MarinMorales MA (2018) Estrogenic Compounds: Chemical Characteristics, Detection Methods, Biological and Environmental Effects. Water, Air, \& Soil Pollution 229: 144.

7. Silva LCM, Brotto ME (2014) NITRATO EM ÁGUA: OCORRÊNCIA E CONSEQUÊNCIAS. Escola Superior de Química, Faculdades Oswaldo Cruz. São Paulo - SP.

8. Wang GS, Deng YC, Lin TF (2007) Cancer risk assessment from trihalomethanes in drinking water. Science of the Total Environment 387(1-3): 86-95.

9. Tonhato (2015) Uso do tanino vegetal como agente floculante de microalgas: estudo de caso de tratamento de efluente de cervejaria. Dissertação de mestrado em engenharia química. UNIOESTETOLEDO.

10. http://www.ceramicastefani.com.br 